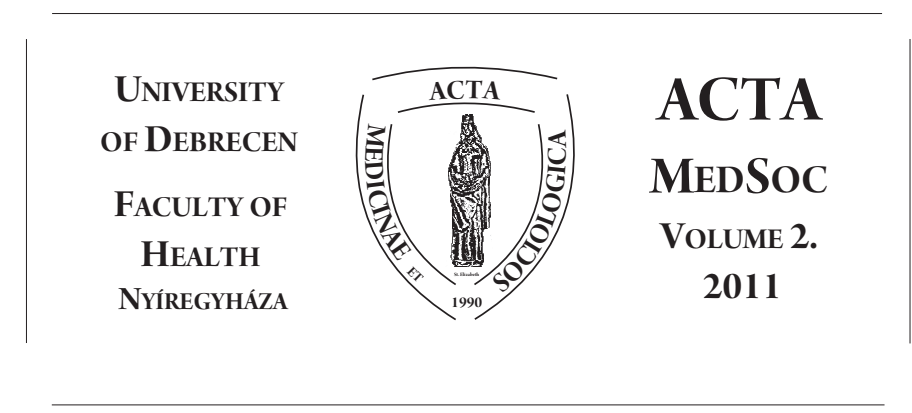

\title{
Szkizofrénia, antipszichotikus gyógyszerek és a szürkeállomány
}

\author{
Bánki M. Csaba \\ Sántha Kálmán Szakkórház Nonprofit Kft., Nagykálló
}

DOI: $10.19055 / \mathrm{ams} .2010 .2 / 2 / 1$

A huszadik század végéig többé-kevésbé általános felfogás szerint a neurológia az idegrendszer organikus (= kimutatható szervi, tehát „valódi” elváltozásokkal járó) betegségeivel foglalkozik, a pszichiátria pedig a „funkcionális” zavarokkal. Sokáig a legsúlyosabb pszichotikus betegségekról, így a szkizofréniáról is azt feltételezték, hogy a tüneteket az agy valamiféle homályos „múködési zavarai” hozzák létre, melyek mögött nincsenek ,valóságos” (anatómiai, élettani) eltérések. Nem nehéz tettenérni a karteziánus hagyományok dualizmusát: a testi tünetek mögött ösztönösen testi (,szervi”), a főleg viselkedési és gondolkodási zavarokban megnyilvánuló „lelki” tünetek mögött ezzel szemben lelki („funkcionális”) rendellenességet sejtettünk. Többek közt ez magyarázza a pszichotikus betegségek orvosi, biológiai kutatását ma is körülvevő gyanakvást, idegenkedést, az olykor indulatos ellenérzéseket. A tényleges adatok ugyanis ma sem elég közismertek. Bár a szkizofrén betegek agyában már évtizedekkel ezelôtt is leírtak anatómiai eltéréseket, de fôleg csak poszt mortem a boncasztalon, amit sokféleképpen lehetett értelmezni. Az igazi előrelépést az in vivo anatómiai és funkcionális képalkotó módszerek (MRI, PET, SPECT, stb) megjelenése tette lehetôvé. Velük egyidôben terjedt el a pszichiátriai diagnózis és a tünetrögzítés standard, reprodukálható technikája. Azóta a szakirodalomban lassan alig követhető az ellenőrzött megfigyelések, mért adatok sokasága, amelyek - az ellentmondások ellenére - egyre világosabban rajzolják körül a szkizofréniás betegség neuroanatómiai és kórélettani jellemzóit. 


\section{A szkizofrénia korszerü definíciója}

A pszichotikus betegségek közös jellemzője az érzékelés és a gondolkodás olyan megváltozása, ami károsítja a beteg valóságészlelését („realitáskontrollját”). A hallucinációk, a téveszmék, a beszéd és a viselkedés bizarr jelenségei azonban sokféle mentális zavarban elófordulnak, egy-egy ilyen tünet megjelenése önmagában még nem jelent diagnózist. Szkizofréniáról csak akkor beszélünk, ha

• több jellemzô pszichotikus tünet észlelhetô egyidejúleg és tartósan,

- a tünetek legalább hat hónapja megszakítás nélkül fennállnak,

- ezalatt a beteg funkcióképessége (életminôsége) egyértelmúen és súlyosan romlik,

- a tüneteket nem más mentális zavar, testi betegség, vagy kémiai szer idézi elő.

A valóságos kritériumok természetesen ennél jóval precízebbek és részletesebbek. Bár a diagnózis ma is a pszichológiai tüneteken alapul, ezek a régen közmondásos szubjektív benyomások helyett nemzetközi szakmai konszenzuson alapuló közvetlen, standardizált megfigyelésre épülnek.

\section{Szkizofrénia és a szürkeállomány}

Már a huszadik század elsô felében észrevették, hogy szkizofrén betegekben gyakori az agykamrák tágulata (ami az agyállomány zsugorodását-sorvadását jelezheti), valamint a kérgi szürkeállomány elvékonyodása fóleg a temporális lebeny és a hippocampus területében. Késôbb a neuroradiológia, majd a modern képalkotó technika ennél sokkal több eltérést figyelt meg, egy részüket még a mai gyógyszeres kezelések elterjedése elôtt. Csak példaképpen: agykamra-tágulatot találtak a vizsgált betegek 73\%-ában, kérgi szürkeállomány-csökkenést a betegek 85\%-ában. A vizsgálatok frontális lebenyre lokalizált eltéréseket jeleztek legalább 60\%-ban, temporális térfogatcsökkenést 70\%-ban, az amygdala és a hippocampus zsugorodását 77\%-ban, a bazális ganglionok anomáliáit 65\%-ban, a thalamus és a corpus callosum állományának csökkenését 70-75\%-ban (McCarley és mtsai, 1999). Korán észrevették azt is, hogy az anatómiai eltérések egy része - gyakran enyhébb formában - a szkizofrén betegek (még?) egészséges hozzátartozóiban is kimutatható, míg mások a betegséggel látszanak összefüggeni. Az utóbbit szembeötlően példázza egy egypetéjú ikerpár agykamráinak párhuzamos radiológiai képe (1.ábra): a vizsgálat idején egyikük egészséges volt, míg a másikuk már évek óta szkizofréniában szenvedett (Woolley és mtsai, 2005).

Az is kiderült, hogy az ilyen anatómiai eltérések előre jelezhetik a szkizofrénia várható lefolyását: számos vizsgálat szerint a nagyon kifejezett kamratágulat rossz 


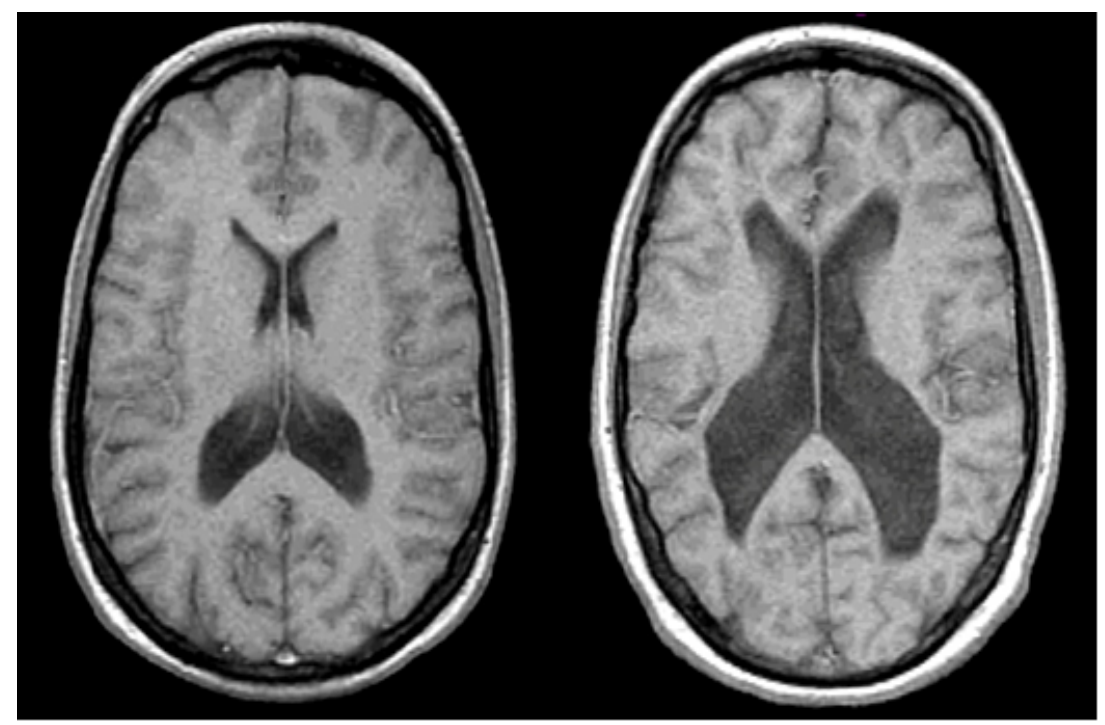

1. ábra. Szkizofréniára diszkordáns egypetéjû ikerpár agykamráinak összehasonlító felvétele: baloldalon az egészséges, jobboldalon a szkizofrén testvér képe (Woolley és mtsai, 2005).

prognózis jele, enyhébb lefolyású - vagy kezelésre jobban reagáló - betegekben kevésbé gyakori (Staal és mtsai, 2001). Részben ezt támasztja alá az a megfigyelés, hogy krónikus, hosszú évek óta szkizofréniában szenvedô betegek kérgi szürkeállományának különbözô lokális eltérései a betegség időtartamával egyenes arányban kifejezettebbek és súlyosabbak (Velakoulis és mtsai, 2002).

Mi okozza szkizofréniában a szürkeállomány elvékonyodását? Precíz mikroanatómiai vizsgálatok igazolták, hogy sem a neuronok, sem a gliasejtek száma nem csökken - de bizonyos neurontípusok kisebbek, szorosabban helyezkednek el, dendrithálózatuk sokkal szegényesebb, és jóval kevesebb szinapszist képeznek. Ezen túl jelentôsen megváltozik a kérgi neuronstruktúra réteges felépítése, a neuronok jelentős része láthatóan rendezetlenül, „rossz" rétegben helyezkedik el; mindez a korai agyfejlődés patológiájára, neuron-migrációs zavarra utal (Selemon, 2004; Glantz és mtsai, 2006). Ilyen és ehhez hasonló észlelésekból alakult ki fokozatosan a szkizofrénia „hibás idegfejlődési” modellje: eszerint a betegség alapja a központi idegrendszer - genetikusan determinált, illetve a legkorábbi (embrionális) életszakaszban külsố határokra kialakult - átfogó fejlôdési zavara, ami késôbb egyes agyi struktúrák, konkrét neuronhálózatok hibás vagy hiányos kapcsolatrendszerét eredményezi („diszkonnektivitás”). A fejlôdési zavar elméletének erôs érve, hogy az anatómiai elváltozások korán, már a szkizofrénia kezdetén, akár a pszichotikus tünetek megjelenése elótt is kimutathatók. A szkizofrénia ugyanis sokszor „prodromális” tünetek- 
kel: hosszú ideig, akár évekig tartó előjelekkel indul, amelyek inkább kedélyhullámzásra, szorongásra, alkalmazkodási zavarokra hasonlítanak. Egy ilyen prodromális tüneteket mutató 75 fôs csoportban az érintettek 31\%-a vált 1 éven belül pszichotikussá; az induláskor elvégzett MRI azt igazolta, hogy ebben a csoportban már akkor, tehát hónapokkal a pszichózis kialakulása elôtt jóval kifejezettebb volt egyes kérgi területek szürkeállományának csökkenése, mint az egészségesen maradók körében (Pantelis és mtsai, 2003). Funkcionális képalkotó eljárásokkal, mint például funkcionális MRI-vel standard pszichológiai tesztfeladatok során jól mérhetô az élô emberi agy regionális múködésváltozása. Nyelvi feladatok (szófelismerés) például az egészségesekben erôteljesen aszimmetrikus, szinte kizárólag baloldali aktivitásnövekedést okoznak a frontális lebeny területén. Szkizofrén betegekben ez a jellemzố oldalkülönbség eltúnik - már a pszichózis elsô jelentkezésekor, sôt a még egészséges, de „nagy kockázatú” személyekben is majdnem ugyanúgy, mint a krónikus betegekben (DeLisi és mtsai, 2006). Itt és a hasonló vizsgálatokban egyaránt azokat nevezik „nagy kockázatú” személyeknek, akiknek legalább egy közeli hozzátartozója szkizofrén, és akik az elmúlt 1-2 évben valamilyen prodromális tünetet (hangulathullámzást, viselkedésváltozást, irracionális szorongást, szokatlan észleléseket vagy gondolatokat, stb) éltek át. Ezek a nagy kockázatú személyek részben hasonló agyi eltéréseket mutathatnak, mint a szkizofrén - vagy a késôbb szkizofrénné váló - betegek. A hasonlóság mellett mások jelentôs különbségeket találtak, a szkizofréniával összefüggó agykérgi változások tehát specifikusak lehetnek. Egy ausztrál kutatócsoport eredményei szerint krónikus szkizofréniában $(\mathrm{n}=89)$, sốt már az elsố epizód idején is $(\mathrm{n}=46)$ fóképp a hippocampus térfogata csökken, míg a hasonló korú-nemú bipoláris („mániás-depressziós”) betegekben (n=59) inkább az amygdala térfogata változik, és az is ellenkezố irányban - miközben tünetileg mind a két csoport markánsan pszichotikus (Velakoulis és mtsai, 2006). A nagy kockázatú személyek valahol a kettô között helyezkedtek el, bennük mindkét agyi szürkeállomány-struktúra kisfokú, nem szignifikáns csökkenését regisztrálták.

\section{A szürkeállomány progresszív károsodása: az idő agyat öl?}

Szkizofréniában a kérgi szürkeállomány rendellenességei már a betegség kezdetén is kimutathatók, de egyre több adat igazolja, hogy az aktív pszichózis további, idôarányos károsodásokhoz vezet. Sok vizsgálat keresett összefüggést a szkizofrénia indulásakor, az elsô tünetektől az elsô kezelésig eltelt idő hossza és a késóbbi kimenetel között. Csaknem kivétel nélkül azt találták, hogy minél hosszabb a kezeletlen pszichózis tartama, annál rosszabbak a kilátások, annál kisebb a jövóbeli tartós javulás esélye (Marshall és mtsai, 2005). Egyre több adat támasztja alá, hogy ennek egyik tényezôje lehet a kezdeti szürkeállomány-eltérések további, progresszív súlyosbodása az aktív, kezeletlen pszichotikus epizódok során.

Korai serdülőkorban a szürkeállomány bizonyos fokú „megritkulása” genetikailag 
programozott, élettani jelenség és a normális fejlődés részét képezi. Az ilyen korban induló, tehát nagyon korai szkizofréniákban ez a folyamat igen jelentôs mértékben felgyorsulni látszik. Több ilyen csoportot évenként ismételt MRI-vel követve kiderült, hogy a kérgi szürkeállomány átlagos évi vesztesége szkizofréniában sokkal nagyobb (akár évi 5\% is) lehet az azonos korú-nemú, és hasonló értelmi fejlettségú nem-szkizofrén kontrollcsoportokhoz képest (évi 1-2\%). Az utóbbiak szintén mentális (döntôen bipoláris) betegség miatt kezelt fiatalokból álltak, akik a vizsgálatok idején ugyanolyan gyógyszerek hasonló adagjait szedték - vagyis a szürkeállomány progresszív fogyása csakis a szkizofrén csoportban nem magyarázható a gyógyszerek hatásával (Thompson és mtsai, 2001; Vidal és mtsai, 2006). Egy további hasonló vizsgálatban gyermekkori (13 éves kor előtt induló) szkizofréniában szenvedóket hasonlítottak össze azonos korú bipoláris betegekkel és egészséges kontrollszemélyekkel. Mindenkiben legalább két MRI vizsgálatot végeztek - átlagosan 2.5 év különbséggel - és azok adataiból számolták ki a kérgi szürkeállomány átlagos évi fogyását. Az eredmények nagyon egyértelmúek voltak (2.ábra): a gyermekkori hangulatzavarok nem jártak együtt az egészségesekénél nagyobb (tehát természetes) szürkeállomány-veszteséggel, viszont a gyermekkori kezdetú szkizofréniák esetében a károsodás sokkal - átlagosan kétszer-négyszer - súlyosabbnak bizonyult. A különbségek az agykéreg egyes területein kissé különböztek ugyan, de statisztikailag külön-külön is mindenütt szignifikánsak voltak mind az egészségesekhez, mint a hangulatzavarban szenvedőkhöz képest (Gogtay és mtsai, 2004).

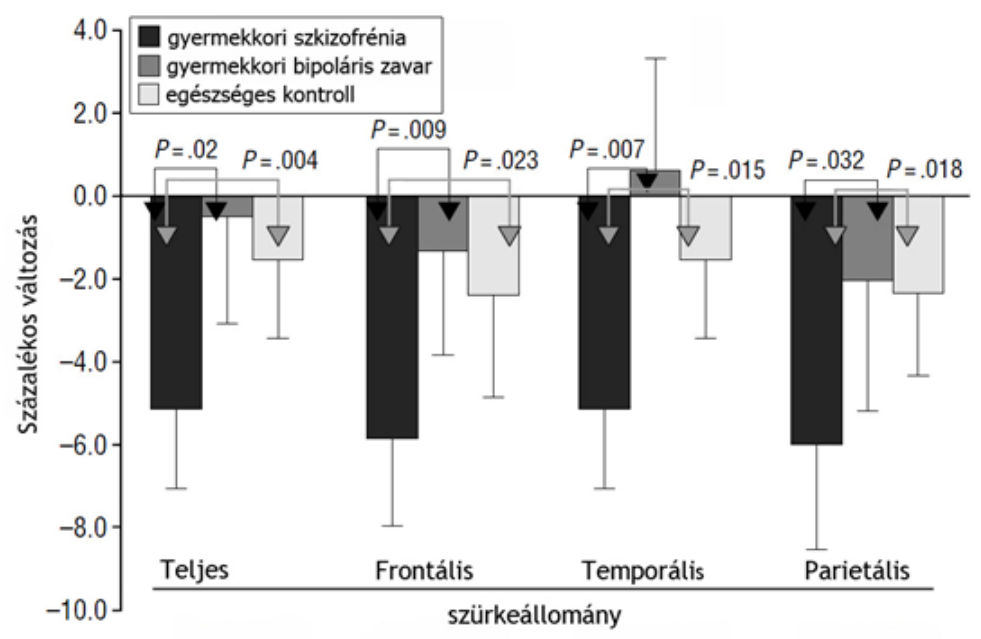

2. ábra. Átlagos évi szürkeállomány-veszteség gyermekkori kezdetû szkizofréniában, bipoláris zavarban, és azonos korú egészséges kontrollszemélyekben (Gogtay és mtsai, 2004). 
Más adatok is azt jelzik, hogy szkizofréniában a neurobiológiai változások a pszichózis tartamával egyenes arányban romlanak. Csaknem száz krónikus szkizofrén beteget öt éven keresztül MRI-vel követve kiderült, hogy a frontális lebeny szürkeállományának progresszív vesztesége az újabb és újabb tüneti relapszusok, tehát a kiújulások és a rehospitalizációk számával egyenes arányban nő (Cahn és mtsai, 2004). Részben ez is magyarázhatja azt a szkizofréniában régóta ismert klinikai tényt, hogy minden egyes visszaeséssel romlik a következő javulás esélye és a kezelés hatásossága. Míg az első epizódos betegek többsége a megfelelő kezelésre 4 hét alatt reagál, legközelebb ehhez már 7 hét, a harmadik visszaesés után pedig átlagosan 24 hét kell (Lieberman és mtsai, 1996). Az aktív pszichotikus állapotban töltött idő hossza egyenesen arányos a szürkeállomány progresszív veszteségével és a növekvố kamratágulattal (Cahn és mtsai, 2009). Ráadásul az utóbbi változás, vagyis az agykamrák idôvel fokozódó tágulata a szkizofrénia várható kimenetelével is szorosan összefüggeni látszik, nagyobb mértéke a rosszabb prognózis elójele (Lieberman és mtsai, 1996). Az ismert kutatási eredmények többsége tehát azt igazolja, hogy szkizofréniában már a kezdetkor észlelhetók agykérgi anomáliák, de ezek az aktív pszichózis során jelentôsen súlyosbodnak. Más szavakkal: a szkizofréniás betegségben „time is brain” (aki időt nyer, agyat ment).

\section{Antipszichotikus gyógyszerek: ártanak vagy védenek?}

Az 1952-ben véletlenül felfedezett antipszichotikumok első generációját - mellékhatásaik után - „neuroleptikum”-nak is nevezték; megjelenésük forradalmasította a pszichiátriát és gyökeresen megváltoztatta a kórházi osztályok életét. Csakhogy a kezdeti ámulatból nemsokára hétköznapi rutin lett, ezzel párhuzamosan előtérbe kerültek a gyógyszerek korlátai és mellékhatásai. Akik a szkizofréniát - a szaporodó kutatási eredmények ellenére - továbbra is kizárólag pszichológiai problémának akarják látni, érthetően idegenkednek egy „lelki betegség” bármiféle gyógyszeres kezelésétôl. Ôk bizonygatják azt az önellentmondást, hogy az antipszichotikus szerek egyszerre lennének hatástalanok, és ugyanakkor agykárosító hatásúak. Azzal érvelnek, hogy ezek a szerek mellékhatásként mozgászavarokat okozhatnak (ami a régi neuroleptikumokra igaz), máskor pedig egyenesen azzal, hogy az antipszichotikumok megváltoztatják az agyi receptorok tulajdonságait, rajtuk keresztül pedig az agy biológiai állapotát; szerintük ez lenne a „neurotoxicitás” bizonyítéka (Whitaker, 2004). Csakhogy kivétel nélkül minden létezó gyógyszer attól gyógyszer, hogy a neki megfelelő receptorokra hat és azokon keresztül biológiai változásokat idéz elő - a közhely tehát nem a „toxicitás”, hanem éppenséggel a hatásosság bizonyítéka. Ha a gyógyszerek idéznék elô szkizofréniában a szürkeállomány sokszorosan igazolt veszteségét, akkor ez csakis a kezelt betegekben lenne észlelhető; az ismert vizsgálatok ennek az ellenkezőjét igazolják, sok adat pedig a neuroleptikumok előtti időkból származik. Gyógyszerszedéssel aligha lenne magyarázható, hogy a szkizofrén be- 
tegek egészséges rokonai is gyakran mutatnak hasonló anatómiai eltéréseket. Ha gyógyszerártalomról lenne szó, akkor az a gyógyszeradag növelésével nyilvánvalóan súlyosbodna, ám egy célzott vizsgálat ennek éppen az ellenkezőjét találta (Cahn és mtsai, 2002). Szkizofrén betegek egy éves követése során az agykérgi szürkeállomány MRI-vel mért fogyása fordított arányban állt a kumulált gyógyszerdózissal. Ez inkább azt jelenti, hogy a gyógyszerek valamilyen mértékben kivédték a szkizofréniával együttjáró károsodást ...

Kétségtelen tény, hogy a gyógyszeres kezelés mérhetô agyi változásokat idéz elő. A striatumban például már 4 heti antipszichotikus kezelés közel 5\%-nyi térfogatnövekedéssel járhat - de csakis azokban, akik a kezelésre jól reagálnak (Taylor és mtsai, 2005). Hasonló mértékú az anatómiai változás mindkét oldalon a thalamus területében is, és ott úgyszintén szorosan korrelál a klinikai javulással. Ennek jelentőségét az adja, hogy éppen a thalamus térfogata kezeletlen szkizofréniás betegekben nagyon jelentősen, akár 30-35\%-kal is csökkenhet. A változás tehát egyértelmúen a normalizálódás irányába mutat (Strungas és mtsai, 2003), amit nagyon nehéz lenne „toxikus” hatásként értelmezni.

Igaz, hogy az elsố generációs antipszichotikumok, tehát a „neuroleptikumok” különféle kínzó, kellemetlen és szembeötlő, stigmatizáló, a beteget magatehetetlenné tevő, egyes esetekben akár (élet)veszélyes mozgászavarokat okozhatnak. Ez volt az egyik fő oka a gyógyszercsoport intenzív továbbfejlesztésének, ami - lassan húsz éve - a második generációs antipszichotikumok (2GAP, más néven „atípusos szerek”) megjelenését eredményezte.

\section{A második generációs szerek és a szürkeállomány}

Az ismert kutatási adatok szerint nem a gyógyszerszedés, hanem a kezeletlen szkizofrénia okozza a szürkeállomány legnagyobb mértékủ fogyását. Szkizofréniában az idố agyat öl - de egyáltalán nem mindegy, hogy mivel próbáljuk ennek útját állni. Az elsó generációs szerek az agyi dopamin $D_{2 / 3 / 4}$ receptorainak blokkolásán keresztül csökkentik a „pozitív” pszichotikus tüneteket (így a hallucinációkat és a téveszméket) de ugyanez magyarázza a mellékhatásként fellépó mozgászavarokat is. A 2GAP szerek esetében ez a kétféle hatás markánsan szétválik: az antipszichotikus hatás erősebb és teljesebb (a „negatív” tünetekre: az érdektelenségre, indítékszegénységre, valamint a kísérő depresszióra is kiterjed), ugyanakkor terápiás adagban alig vagy egyáltalán nem okoznak mozgászavart. Ennek hátterében az agyi receptorkötôdés szélesebb spektruma vagy eltérô dinamikája áll, de ennek részleteit még ma is kutatják. Ugyanakkor egyre több kutatási adat jelzi, hogy ezek a 2GAP szerek - a régi neuroleptikumoktól eltérôen - képesek lehetnek a szkizofrénia szürkeállomány-károsító hatását is kivédeni.

Korábban kezeletlen, elsố epizódos szkizofrén betegek egyik csoportját ismételt MRI vizsgálatok mellett egy évig hagyományos neuroleptikummal (haloperidollal), másik csoportját pedig 2GAP szerrel (olanzapinnal) kezelték. A megfigyelési periódus végén azt találták, hogy a haloperidollal kezelt csoportban az agykérgi 
szürkeállomány - a kezeletlen szkizofréniára jellemzó változáshoz hasonló ütemben - tovább fogyott, míg az olanzapinnal kezelt betegekben a folyamat jelentôsen lelassult: szignifikánsan kisebb kiterjedésú volt, kevesebb agyterületet érintett, és a mértéke ott is sokkal kevésbé volt kifejezett (Thompson és mtsai, 2009). Különösen akkor vált ez szembeötlővé, amikor az ismételt méréseket 3 havonta elemezték: az olanzapin csoportban a progresszió az elsố negyedév után gyakorlatilag megállt, míg a haloperidollal kezelt csoportban tovább folytatódott és egyre erôteljesebbé vált. A kétféle gyógyszertípus tehát nagyon különböző módon hat a szkizofrén betegek agykérgi szürkeállomány-veszteségére: a haloperidol láthatóan nem befolyásolja, viszont a 2GAP szerek valamiképpen lelassítják, mérséklik a károsodást. Számos más vizsgálat eredménye is ugyanezt látszik igazolni. Különbözö antipszichotikumot szedő krónikus szkizofrén betegek 5 éves követése során az derült ki, hogy az első generációs haloperidol napi adagja semmiféle kapcsolatban nincs a szürkeállomány évenkénti veszteségével, azonban két különböző 2AGP szer (az olanzapin és a clozapin) növekvố adagjai egyenes arányban csökkentik a mérhető károsodást (Van Haren és mtsai, 2007). A valóság tehát éppen az ellenkezője annak, mint amit a gyógyszerek „toxikus” hatásának elmélete sugallna ...

Az egyik legnagyobb ilyen vizsgálatban 142 elsô epizódos szkizofrén beteget (és 52 egészséges kontrollszemélyt) követtek egy induló, majd 12, 24, 52 és 104 hét után megismételt MRI-vel. A betegeket véletlenszerúen két csoportba sorolták és szigorú kettôs-vak feltételek között 2 éven át vagy haloperidollal, vagy olanzapinnal kezelték. Az eredmények lényegét a 3.ábra foglalja össze: míg a haloperidollal kezelt csoportban a kérgi szürkeállomány markánsan progresszív vesztesége folytatódott, addig az olanzapint szedô betegekben ez a folyamat lényegében megállt; a két csoport közti különbség már 12 hét után egyértelmú volt és mindvégig szignifikáns maradt (Lieberman és mtsai, 2005). Az olanzapin csoportban mért anatómiai változások statisztikailag nem különböztek az egészséges - és természetesen gyógyszermentes - kontrollszemélyekétól.

A kétféle gyógyszertípus tehát nem csupán a szkizofrénia tüneteire, hanem annak neurobiológiai hátterére is különbözóképpen hat. Ennek magyarázata a 2GAP szerek jelentôsen eltérô regionális receptorkötődése lehet az agyon belül. Míg a régi neuroleptikumok erősen kötődnek a törzsdúcok, azon belül is különösen az extrapiramidális központok (striatum, putamen) valamint az insula és a cinguláris kéreg neuronjainak dopamin-receptoraihoz - ami részben magyarázza a parkinsonszerú mellékhatásokat - addig a 2GAP szerek ezekben a területekben alig fejtenek ki hatást, ugyanakkor intenzíven kötődnek a thalamus érintett receptoraihoz (Dazzan és mtsai, 2005). Ebból következhet, hogy a különbözó gyógyszerekkel végzett kezelés a szubkortikális területek szürkeállományában is eltérô változásokkal jár együtt: a neuroleptikumokkal szemben a $2 \mathrm{GAP}$ szerek a törzsdúcokon belül kizárólag a thalamus térfogatát növelik, ami a szkizofréniában észlelt eltérések normalizálódásának irányába mutat.

Egyes megfigyelések szerint a szkizofréniás betegek progresszív szürkeállományveszteségét a $2 \mathrm{GAP}$ szerek nem is csupán lelassítják, hanem bizonyos mértékig 


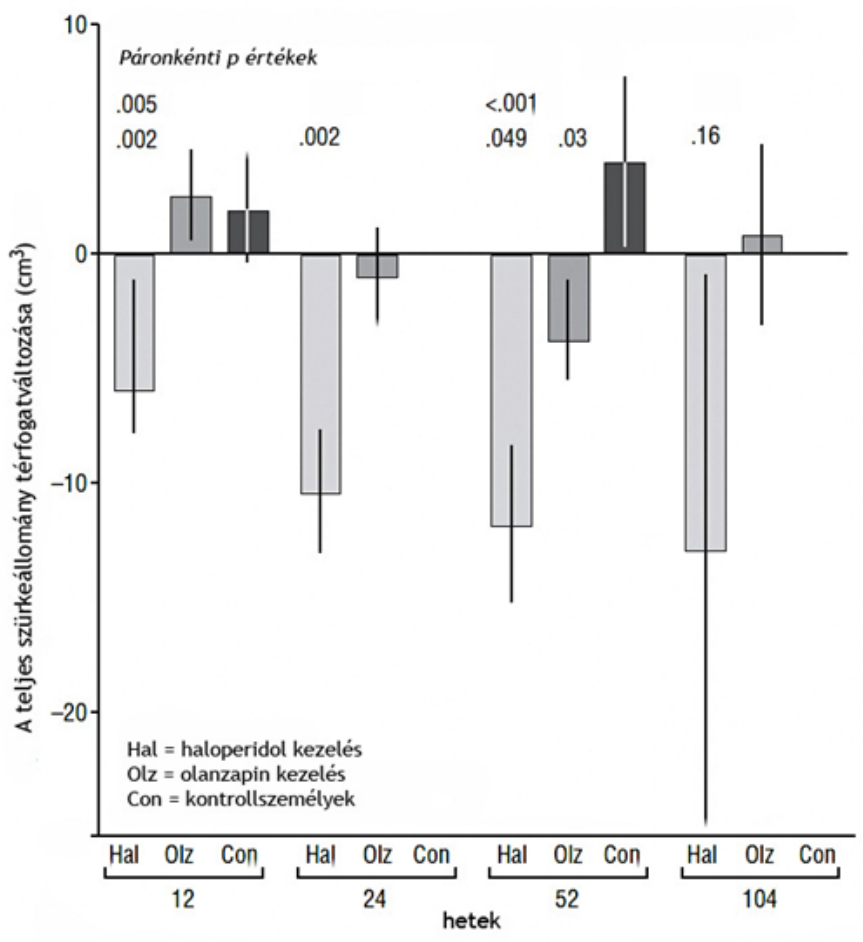

3. ábra. Elsố és második generációs antipszichotikumok (haloperidol és olanzapin) eltérô hatása a kezelt szkizofrén betegek agykérgi szürkeállományára (Lieberman és mtsai, 2005).

vissza is fordíthatják. Egy kis létszámú $(\mathrm{n}=19)$ csoportban a betegek egyharmada haloperidolt, kétharmaduk 2GAP gyógyszert kapott. A négy hét elteltével megismételt MRI a haloperidolt szedők agykérgi szürkeállományában semmiféle változást nem talált (ami 4 hét alatt nem is volt várható), ugyanakkor a 2GAP csoport betegeinél már ennyi idố alatt is szignifikáns növekedést észleltek (Garver és mtsai, 2005). Úgy tûnik tehát, hogy szkizofréniában az idô valóban kritikus tényezô (,time is brain"), és egyáltalán nem mindegy, hogy közben mivel kezeljük.

\section{Szürkeállomány-védô mechanizmusok?}

A szkizofréniában tapasztalt progresszív és jelentôsen felgyorsult szürkeállományfogyás egyik feltételezett mechanizmusa az idegsejtek programozott sejthalálának, az apoptosis folyamatának kóros fokozódása. Ez a nagyon bonyolult, de egyre 
világosabban értett mechanizmus különbözó genetikai vagy környezeti hatásokra aktiválódik, és a biokémiai láncolat elemei szkizofréniában túlmúködni látszanak (Glantz és mtsai, 2006). Ma még kérdéses, hogy ezt a folyamatot a 2GAP gyógyszerek képesek-e a régi neuroleptikumoktól eltérô módon befolyásolni.

Azt viszont sikerült igazolni, hogy a neuronok folyamatos táplálásáért és életben tartásáért felelôs neurohormonok, az ,idegnövekedési faktorok” reagálnak az antipszichotikus kezelésre, méghozzá gyógyszertípustól függóen. A plazmában mérhető NGF (nerve growth factor) szint például az elsố epizódos, még kezeletlen szkizofrén betegekben radikálisan, csaknem az egyharmadára csökken. A huzamosan régi neuroleptikumokkal kezelt krónikus betegekben évek múlva ugyanilyen alacsony szintek mérhetôk - ezzel szemben a 2GAP szereket szedő betegekben több mint kétszeres plazma NGF szint-emelkedés tapasztalható, ami a normalizálódás felé mutat és az egészséges átlagérték 70-75\%-át is eléri (4.ábra). Az NGF plazmaszintjének emelkedése ráadásul egyenesen arányos a szkizofrénia „pozitív” és „negatív” tüneteinek javulásával is (Parikh és mtsai, 2003).

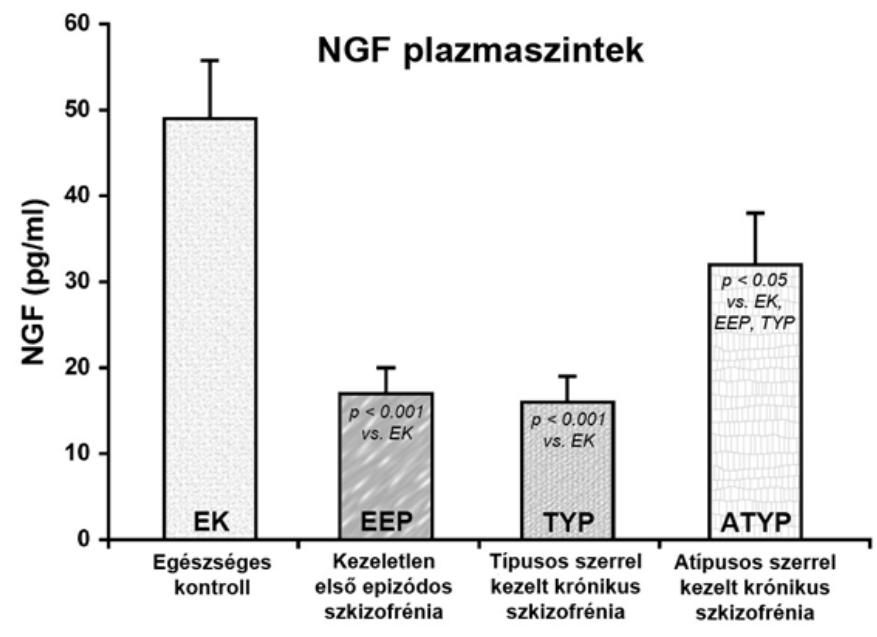

4. ábra. Az ,idegnövekedési faktor” (nerve growth factor, NGF) átlagos plazmaszintje kezeletlen, és különböző antipszichotikum-típusokkal kezelt szkizofrén betegekben (Parikh és mtsai, 2003).

Csak a legutóbbi két évtizedben vált egyértelmúvé, hogy a korábbi feltételezésekkel szemben az emberi agy felnőttkorban is tartalmaz élô neuronális ôssejteket, amelyek megfelelő körülmények hatására osztódni és differenciálódni képesek, majd a megfelelő helyre vándorolva új neuronokká alakulnak. Az agyi idegsejt-újraképzôdés (neurogenesis) lehetôsége tehát az ember egész életén át fennmarad, bár ennek mértékét a kutatók még vitatják. Az viszont kiderült, hogy ezek a neuronális ôs- 
sejteket dopamin (D2) receptorokat hordoznak, amelyeken át az agyi dopamin a szaporodásukat gátolja. Az antipszichotikus gyógyszerek ezzel szemben D2 receptor blokkolók, hatásukra tehát az ôssejtek aktiválódhatnak és a neurogenesis élénkülhet (Kippin és mtsai, 2005). Bár egyelôre csak állatkísérletben, de ezt közvetlenül is sikerült igazolni (Wang és mtsai, 2004), ahol ráadásul az is kiderült, hogy az olanzapin - egy 2GAP szer - neurogenesist serkentô hatása lényegesen erósebb, mint a haloperidolé. Ma még nem tudjuk megmondani, hogy az idegsejt-újraképzôdést serkentô hatásnak van-e releváns szerepe az antipszichotikumok klinikai hatásában, de maga a folyamat kétségtelenül létezik és biztosan további kutatást érdemel.

Összefoglalva: szkizofrén betegekben a kutatási eredmények egybehangzó többsége az agykérgi szürkeállomány felgyorsult, progresszív fogyását igazolja. A károsodások a betegség kezdetétól, gyógyszermentes betegekben is kimutathatók. A régi, első generációs neuroleptikumok ezeket a változásokat nem befolyásolják, ezzel szemben a második generációs szerekkel folytatott kezelés - egyre több kézzelfogható bizonyíték tükrében - képes lehet a progressziót megállítani, sốt bizonyos mértékig akár vissza is fordítani.

\section{Irodalomjegyzék}

1. Cahn W, Hulshoff Pol HE, Caspers E, van Haren NE, Schnack HG, Kahn RS: Cannabis and brain morphology in recent-onset schizophrenia. Schizophr Res 2004, 67: 305-307.

2. Cahn W, Hulshoff Pol HE, Lems EB, van Haren NE, Schnack HG, van der Linden JA, Schothorst PF, van Engeland H, Kahn RS: Brain volume changes in first-episode schizophrenia: a 1-year follow-up study. Arch Gen Psychiat 2002, 59: 1002-1010.

3. Cahn W, Rais M, Stigter FP, van Haren NE, Caspers E, Hulshoff Pol HE, Xu Z, Schnack HG, Kahn RS: Psychosis and brain volume changes during the first five years of schizophrenia. Eur Neuropsychopharmacol 2009, 19: 147-151.

4. Dazzan P, Morgan KD, Orr K, Hutchinson G, Chitnis X, Suckling J, Fearon P, McGuire PK, Mallett RM, Jones PB, Leff J, Murray RM: Different effects of typical and atypical antipsychotics on grey matter in first episode psychosis: the AESOP study. Neuropsychopharmacol 2005, 30: 765-774.

5. DeLisi LE, Szulc KU, Bertisch HC, Majcher M, Brown K: Understanding structural brain changes in schizophrenia. Dialogues Clin Neurosci 2006, 8: 71-78.

6. Garver DL, Holcomb JA, Christensen JD: Cerebral cortical gray expansion associated with two second-generation antipsychotics. Biol Psychiat 2005, 58: 62-66. 7. Glantz LA, Gilmore JH, Lieberman JA, Jarskog LF: Apoptotic mechanisms and the synaptic pathology of schizophrenia. Schizophr Res 2006, 81: 47-63.

8. Gogtay N, Sporn A, Clasen LS, Nugent TF 3rd, Greenstein D, Nicolson R, Giedd JN, Lenane M, Gochman P, Evans A, Rapoport JL: Comparison of progressive cortical gray matter loss in childhood-onset schizophrenia with that in childhoodonset atypical psychoses. Arch Gen Psychiat 2004, 61: 17-22. 
9. Kippin TE, Kapur S, van der Kooy D: Dopamine specifically inhibits forebrain neural stem cell proliferation, suggesting a novel effect of antipsychotic drugs. J Neurosci 2005, 25: 5815-5823.

10. Lieberman JA, Alvir JM, Koreen A, Geisler S, Chakos M, Sheitman B, Woerner M: Psychobiologic correlates of treatment response in schizophrenia. Neuropsychopharmacol 1996, 14(3 suppl): 13-21.

11. Lieberman JA, Tollefson GD, Charles C, Zipursky R, Sharma T, Kahn RS, Keefe RS, Green AI, Gur RE, McEvoy J, Perkins D, Hamer RM, Gu H, Tohen M; HGDH Study Group: Antipsychotic drug effects on brain morphology in firstepisode psychosis. Arch Gen Psychiat 2005, 62: 361-370.

12. Marshall M, Lewis S, Lockwood A, Drake R, Jones P, Croudace T: Association between duration of untreated psychosis and outcome in cohorts of first-episode patients: a systematic review. Arch Gen Psychiat 2005, 62: 975-983.

13. McCarley RW, Wible CG, Frumin M, Hirayasu Y, Levitt JJ, Fischer IA, Shenton ME: MRI anatomy of schizophrenia. Biol Psychiat 1999, 45: 1099-1119.

14. Pantelis C, Velakoulis D, McGorry PD, Wood SJ, Suckling J, Phillips LJ, Yung AR, Bullmore ET, Brewer W, Soulsby B, Desmond P, McGuire PK: Neuroanatomical abnormalities before and after onset of psychosis: a cross-sectional and longitudinal MRI comparison. Lancet 2003, 361: 281-288.

15. Parikh V, Evans DR, Khan MM, Mahadik SP: Nerve growth factor in nevermedicated first-episode psychotic and medicated chronic schizophrenic patients: possible implications for treatment outcome. Schizophr Res 2003, 60: 117-123.

Selemon LD:Increased cortical neuronal density in schizophrenia. Am J Psychiat 2004, 161:1564.

16. Staal WG, Hulshoff Pol HE, Schnack HG, van Haren NE, Seifert N, Kahn RS: Structural brain abnormalities in chronic schizophrenia at the extremes of the outcome spectrum. Am J Psychiat 2001, 158: 1140-1142.

17. Strungas S, Christensen JD, Holcomb JM, Garver DL: State-related thalamic changes during antipsychotic treatment in schizophrenia: preliminary observations. Psychiat Res 2003, 124: 121-124.

Taylor S, Christensen JD, Holcomb JM, Garver DL: Volume increases in striatum associated with positive symptom reduction in schizophrenia: a preliminary observation. Psychiat Res 2005, 140: 85-89.

18. Thompson PM, Vidal C, Giedd JN, Gochman P, Blumenthal J, Nicolson R, Toga AW, Rapoport JL: Mapping adolescent brain change reveals dynamic wave of accelerated gray matter loss in very early-onset schizophrenia. Proc Natl Acad Sci USA 2001, 98: 11650-11655.

19. Thompson PM, Bartzokis G, Hayashi KM, Klunder AD, Lu PH, Edwards N, Hong MS, Yu M, Geaga JA, Toga AW, Charles C, Perkins DO, McEvoy J, Hamer RM, Tohen M, Tollefson GM, Lieberman JA, and the HGDH Study Group: Time-lapse mapping of cortical changes in schizophrenia with different treatments. Cerebral Cortex 2009, 19: 1107-1123.

20. van Haren NE, Hulshoff Pol HE, Schnack HG, Cahn W, Mandl RC, Collins 
DL, Evans AC, Kahn RS: Focal gray matter changes in schizophrenia across the course of the illness: a 5-year follow-up study. Neuropsychopharmacol 2007, 32: 2057-2066.

21. Velakoulis D, Wood SJ, Smith DJ, Soulsby B, Brewer W, Leeton L, Desmond P, Suckling J, Bullmore ET, McGuire PK, Pantelis C: Increased duration of illness is associated with reduced volume in right medial temporal/anterior cingulate grey matter in patients with chronic schizophrenia. Schizophr Res 2002, 57: 43-49.

22. Velakoulis D, Wood SJ, Wong MT, McGorry PD, Yung A, Phillips L, Smith D, Brewer W, Proffitt T, Desmond P, Pantelis C: Hippocampal and amygdala volumes according to psychosis stage and diagnosis: a magnetic resonance imaging study of chronic schizophrenia, first-episode psychosis, and ultra-high-risk individuals. Arch Gen Psychiat 2006, 63: 139-149.

23. Vidal CN, Rapoport JL, Hayashi KM, Geaga JA, Sui Y, McLemore LE, Alaghband Y, Giedd JN, Gochman P, Blumenthal J, Gogtay N, Nicolson R, Toga AW, Thompson PM: Dynamically spreading frontal and cingulate deficits mapped in adolescents with schizophrenia. Arch Gen Psychiat 2006, 63: 25-34.

24. Wang HD, Dunnavant FD, Jarman T, Deutch AY: Effects of antipsychotic drugs on neurogenesis in the forebrain of the adult rat. Neuropsychopharmacol 2004, 29: 1230-1238.

25. Whitaker R: The case against antipsychotic drugs: a 50-year record of doing more harm than good. Med Hypotheses 2004, 62: 5-13.

26. Woolley J, McGuire P: Neuroimaging in schizophrenia: what does it tell the clinician? Adv Psychiat Treatm 2005, 11: 195-202.

Prof. Dr. Bánki M. Csaba: osztályvezető főorvos, pszichiáter, farmakológus Sántha Kálmán Szakkórház Nonprofit Kft., 4321 Nagykálló, Szabadság tér 13. 